\title{
Academic Boredom: An Underestimated Challenge in Schools
}

\author{
Gül Özerk*
}

\author{
Received \\ Revised \\ Accepted \\ $\mathrm{DOI}$ \\ 8 March 2020 \\ 2 August 2020 \\ 19 September 2020 \\ 10.26822/iejee.2020.177 \\ Correspondance Details: Gül Özerk. \\ Educational Psychological Caunseling Services, \\ Oslo, Norway. \\ E-mail: ozerk.gul@gmail.com \\ ORCID: http://orcid.org/0000-0001-6205-0300
}

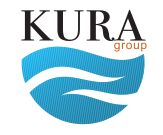

Copyright (c)

www.iejee.com

ISSN: 1307-9298

(c) 2020 Published by KURA Education \& Publishing. This is an open access article under the CO BY- NC- ND license. (https://creativecommons. org/licenses/by/4.0/)

\begin{abstract}
Academic boredom is a complex and underestimated problem in schools in many countries. The research on this phebomenen is mostly from Germany and Northern America. During the last two-three decades several studies have highlighted some aspects of academic boredom and its relationship to motivation and school-based learning behavior and outcomes. This paper addresses and trys to clarify academic boredom as an important concept from several angles and highlights new and promising improvements in the field. A special emphasis is laid on preseting the extend and indentifying features, signs and antecedants. Furhermore the paper discusses academic boredom as a negative deactivating goal achievement emotion, and illuminate academic boredom as an antecedent and concequence.
\end{abstract}

\section{Keywords:}

Boredom, Academic Boredom, Concequences of Academic Boredom, Goal Achievement Emotions, Academic Emotions, Control-Value Theory

\section{Introduction}

Boredom is a well-known word and a natural part of our everyday language. Depending on our previous life experiences, the concept of boredom evokes different associations. For many of us it is specially associated with teaching-learning settings in school. Based on the research in the field, academic boredom appears to be a complex phenomenon. As we look closer, it culminates in a key question: What is really academic boredom?

Academic boredom is a relatively new concept, but nevertheless a relevant and growing phenomenon in an educational context. Despite limited research in the field, several researchers claim that boredom in school can be seen as the "plague" of modern society (Daschmann, Goetz \& Stupnisky, 2014; Pekrun et al., 2010). Studies reveal that there is a high incidence of boredom in elementary schoolage children in school settings (Larson \& Richards, 1991, Sørlie \& Nordahl, 1998; Øia, 2011; Daschmann, Goets \& Stupnisky, 2011; Price et al., 2012; Fullan, 2014). The research show that different degrees of boredom can lead to different forms of learning-behavior, and learning-outcomes in school. 
Awarenes of and knowledge about academic boredom is particularly important for teachers, school leaders, and educational psychologist. This is due to the fact that it can help the professionals to better understand students' behavior patterns in the classroom, and initiate preventive measures. In addition their knowledge can support students in developing their own strategies to overcome boredom in a beneficial way.

\section{The Purpose of the Article}

The purpose of this article is to highlight the concepts of 'boredom' and 'academic boredom', and discuss the extend, feauters, signs, antecedents and precusors. Furthermore it attempts to clarify boredom as a consequence of teaching-learning and subject matter related factors.

In this article, academic boredom is treated as an environmental-related phenomenon. Thus 'trait boredom' (general boredom tendency), which is seen as a predisposed personality trait (Eastwood et al., 2012; Vogel-Walcutt et al., 2012) will not be addressed. Moreover, the main focus will be on academic boredom among students in elementary and secondary schools.

\section{The Extend of Academic Boredom}

In their comprehensive meta-analysis of studies of the relationship between boredom and academic outcomes Tze and her colleagues (2016) claim that the experience of academic boredom amoung students may be universal. Studies in 90 s such as Larson and Richards (1991) found that about 36\% of middle school students experienced their classwork time as boring. Aspecially for 5th to 8th graders, there was an increasing trend for boredom. With regard to homework time, $40 \%$ of the students reported it as boring. In a study of boredom among 3rd to 5th graders Patrick, Skinner and Connell (1993) found that boredom has negative impact on the students' behavior.

One of the earlier studies on academic boredom in Norway was conducted by Sørlie \& Nordahl (1998) among approximately 1000 middle school students (13-16-year olds). The result of this study revealed that around $60 \%$ of the students experienced the school as monotonous and boring. They describe boredom as passivity, lack of interest and a form of introverted resistance to the teaching conditions by the students. Furthermore they consider boredom as an emotional form of reaction. It is obvious that this makes it difficult for the school to accomplish its goals in terms of communicating values, attitudes, and creating optimal conditions for learning of knowledge and skills. The teachers experience that the students' boredom implies a mental absence in the teachinglearning settings. They consider this as a bigger problem than externalizing and challenging behavior they experience in the class.

In an another study among approximately 2000 Norwegian middle school students Thuen \& Bru (1999) found that every fourth student experienced schoolwork as uninteresting, boring and meaningless.

Some empirical studies among young school children during the last two decades focuses on the relationship between academic boredom and the students' motivation, learning strategies, and achievement. At the same time they address the relationship between academic boredom and the features of the subject matter. Stavrova and Urhahne (2010) studied relationship between boredom and motivation among 96 middle school students and found that the higher levels of boredom is associated with lower levels of intrinsic motivation to learn. According to Fritea and Fritea (2013) academic boredom is caused by teaching-learing situations and has negative impact on the elementary school children's learning outcomes.

In a study among approximately 4000 Norwegian middle school students, Øia (2011) found that 25\% of the students are bored at school. This study suggests that this may be a consequens of too much theorethical subject matter in the schools. A study by Goetz, Frenzel \& Pekrun (2007 referd in Daschmann et al. 2011) in Germany, claimes that students get bored about $50 \%$ of the time in each subject hour. In their sample there were 350000 students between 11 and 18 -year of age. Another German study by Daschmann et al., (2011) found that up to $43 \%$ of the students in math classes felt bored. Price et al. (2012) found that approximately $98 \%$ of students experience boredom in some part of their school time. Approximately 33\% of the students felt that they were bored every day, $50 \%$ of the students had skipped school and 1 in 5 had considered opting out of school. Fullan (2014) reports from the Canadian context that two thirds of happy and committed kindergarten children will be bored at school before they start in 9th grade. These are high numbers and they tell us that the incidence of boredom in school is high and that academic boredom can lead to negative consequences for students.

There are however some ambiguities in these studies due to the fact that they do not explain clearly what they mean by 'academic boredom', they lack a common understanding of the feauters, signs, antecedents and precusors of academic boredom. In addition, they focus on partly or fully different factors 
embedded in the school subjects, teaching-learning settings, and students behavior and students feelings in their study/measurement of academic boredom. During the last two decades, several researchers have tried to explain academic boredom from different approaches. They address several features of academic boredom, especially student behaviors and feelings associated with it. However in earlier studies, the concept of academic boredom, is not systematically and clearly discussed by all researchers in its breadth. In the following sections, these approaches will be presented and elaborated. The aim is to contribute to the improvement of common understanding of academic boredom.

\section{Academic Boredom-One of Many School-Related Emotions}

Recent research in educational psychology has begun to focus more on the diversity of emotions students experience in the classroom. Several studies by Pekrun et al. $(2007,2014,2018)$ show that students experience a wide range of positive and negative emotions in the school situation. They call them academic achievement emotions. In our daily speech, we label these emotions as joy, hope, pride, anxiety, anger, frustration, well-being, helplessness and last but not least boredom. Pekrun et al. (2007) separate these emotions into four categories:

1) positive activating,

2) positive deactivating,

3) negative activating and

4) negative deactivating emotions.

The achievement emotion of academic boredom falls into the last category of 'negative deactivating emotions'. The reason is that academic boredom is perceived as unpleasant, and involves a reduction in physiological activation (Pekrun et al. 2010).

It may seem like school-based achievement emotions, apart from anxiety, have been neglected, despite their strong presence in the classroom and relation to students' school-based learning and performance, development, health, and well-being (Pekrun et al., 2002, 2014, 2018). One possible reason for this may be that boredom is an invisible and 'quiet' emotion compared to, for example, a more manifested affective state such as anger. From teacher's perspective, it may seem that boredom lacks the interrupting character which anger brings with it in a classroom situation. On the other hand, it can be seen from a clinical perspective where it may appear that boredom lacks a psychopathological relevance, compared to e.g. anxiety (Pekrun et al., 2010). However, this does not mean that boredom is less harmful than other negative emotions. Even if students who experience boredom do not have disruptive behavior during class, or while working with their school subjects in the short run, we cannot overlook the negative impact boredom can have in the long run.

Boredom encompasses reduced motivation and lack of use of suitable learning strategies that weaken students' ability to achieve academic goals (Daniels et al., 2008; Tze, Klassen \& Daniels, 2014). Students, who are bored, cannot realize their cognitive and metacognitive potential, and thus there is a higher risk of many negative consequences, both for their academic and psychosocial development, such as low grades, school absenteeism and dropout (Robinson, 1975; Daschmann et al., 2014; Pekrun et al., 2014). This tells us something about the fact that we must take this phenomenon seriously. Research shows us that students get bored far more often than they worry (Goetz et al., 2006; Nett, Goetz \& Hall, 2011). This negative deactivating emotion turns out to be quite common among students in school-settings. This necessitates a closer look at the phenomenon. Therefor it is of utmost importance to know what one has to look at and what kind of student behaviors and student feelings one can relate to academic boredom.

\section{Signs of Academic Boredom}

When students complain about boredom, they do not necessarily have to talk about the same thing. We can look at boredom as a puzzle with different components. We can look at the following six components as signs of boredom (Pekrun et al., 2010):

a) a state of unpleasant feelings

b) lack of stimulation

c) low physiological activation

d) prolonged subjective experience of time

e) tendencies to escape from the situation thru thought migration

f) slow monotonous voice use.

Such an experience profile means that boredom consists of affective, cognitive and motivational components, and in addition expressive components. The affective components mean that students who are bored are feeling an inner discomfort. The cognitive components are expressed when the students' subjective sense of time becomes slower. The motivational components of boredom are expressed as the students' desire to escape from the situation. 


\section{iejee}

The expressive components are the ones that make the boredom visible. It is shown by facial and body expressions.

This complex composition of boredom makes it difficult to find an universal definition. From his psychoanalytical perspective Greenson (1953) expresses the complexity of the phenomenon of boredom as something:

... which is easier to describe than to define. The uniqueness of the feeling of being bored seems to depend upon the coexistence of the following components: a state of longing and inability to designate what is longed for; a sense of emptiness; a passive, expectant attitude with the hope that external world will supply satisfaction; a distorted sense of time in which time seems to stand still (p.7).

There are several researchers, like Greenson, who have expressed how demanding it is to define boredom. It can often seem easier to explain it than to define it. One of the reasons for this may be the fact that boredom is not always directly observable (Daschmann et al., 2011; Götz et al., 2013). In educational and psychological research, it is not uncommon to try to investigate and figure out something that is not directly observable. It may therefor be an important contribution to the field to highlight the emerging approaches to academic boredom.

Daschmann and her collegues (2011) present the following eight 'precursors of academic boredom' or 'antecedents of boredom':
a) Monotony
b) Lack og meaning
c) Opportunity costs
d) Being over-challanged
e) Being under-challanged
f) Lack of involvement
g) Teacher dislike
h) Generalized boredom (p. 427)

Like the aforementioned well defined six components as signs of boredom presented by Pekrun et al. (2010), these eight antecedents of boredom presented by Daschmann et al. (2011) make it easy to use them in reseach with stronger concept validity with identificable and comparable features.

During the last decade, several researchers have tried to find a comprehensive definition of 'academic boredom' by discussing nuances embedded in the psychological spectrum of emotions that characterize boredom.

\section{Academic Boredom as a Feeling of Deficiency}

Based on the above discussion of boredom, we can say that students' experience of boredom at school is often seen as an affective condition in the classroom that consists of a number of visible and invisible factors. Pekrun et al. (2010), for example, describe boredom as a "... affective state composed of unpleasent feelings, lack of stimulation, and low physiological arousal" (p. 532). The affective, cognitive, motivational and expressive components of boredom make it different from other negative goal achievement emotions, such as anger, anxiety or shame. In the seemingly hopeless boredom, there is a desire to engage in an activity. But how one can engage herself/himself, and in which activity one wants to engage in, is very difficult to find out. Some researchers describe this condition as: "... wanting to, but not being able to engage in satisfying activity" (Eastwood et al. 2012, p. 483). This conception of the phenomenon is also supported by other researchers who define boredom as "... the unfulfilled desire for satisfying activity ... (Gerritsen et al., 2013, p. 27). All of the descriptions above tell us something about the psychological needs that boredom creates in humans, but the reason for this is unknown. This may be the reason why not one definition manage to capture the breadth of the learning-related emotion, academic boredom.

\section{Academic Boredom as a Consequence}

We can also approach academic boredom from a developmental perspective. Some researchers argue that school-based boredom leads to a limited commitment to academic learning activities that lack personal value (Pekrun et al. 2014; Daschmann et al., 2011). This is an explanation of why some students direct their attention to more personal rewarding activities. This is in line with the approach of other researchers who consider boredom as a "... state ranging from mild to severe unpleasantness, which people describe as a feeling of tedium, meaninglessness, emptiness, wearisomeness, and lack of interest or connection with the current environment" (Sundberg et al., 1991, p. 210). Other researchers claim that boredom can be seen as the opposite of a number of emotional states such as interest, enthusiasm, involvement, commitment, flow and optimal stimulation (Acee et al. 2010). In this view boredom is a negative and deactivating emotion that occurs when students experience a lack of control over school-based activities, due to either being too difficult or too easy, and / or when they do not see the value in the task they are to perform (Goetz et al. 2006; Pekrun et al., 2007; Tze et al., 2014, Pekrun et. al, 2018).

In this discussion, some researchers argue that boredom most likely can be caused by a lack of 
interest, but it is important not to portray it as the opposite of interest or other positive emotions. In an attempt to clarify the relationship between boredom and interest, Daschmann et al. (2014) claim that

\begin{abstract}
... boredom constitutes more than the absence of interest. Lack of interest is affectively neural and does not cause emotional pain, whereas boredom is emotionally distressing. Due to different affective loads, lack of interest and boredom, also has different motivational consequences (p.23).
\end{abstract}

This also tells us something about the fact that boredom is not the same as being apathetic either, even though it may seem that they have many similarities. In boredom, there is a desire to actually be interested, but there may be external or internal reasons why boredom takes over, and makes it difficult to get out of the situation despite the desire for change.

The research shows various factors that can contribute to boredom in the school situation, such as monotonous and repetitive activities as Hill and Perkins (1985) say "... boredom occurs when stimuli are constructed as subjectively monotonous" ( p. 237). In their research they identified monotonous teaching as one of the main reasons for the occurrence of boredom. Occurrence of boredom may also be related to the students' feeling of subject matter as meaningless or the feeling that the activity is worthless. This means that if students experience a given school assignment as relevant to their needs, it becomes more meaningful or valuable to them and therefore less likely that the activity will provoke academic boredom (Daschmann et al., 2011). It seems that there is a growing agreement in this approach to boredom in school. Other studies investigated whether a lack of sense of meaning and value in working with school subject matter, could lead to boredom in the school situation. The results also indicate that the experience of the teaching material as worthless or meaningless can lead to academic boredom. Even though approaches to explain what causes boredom vary considerably, it is quite obvious that several aspects of classroom teaching can evoke academic boredom in school (Robinson, 1975; Daschmann et al., 2011). This necessitates a closer look at boredom in the light of Pekrun's (2006) 'control-value theory'.

Academic boredom as a goal achievement emotion In control-value theory, goal achievement emotions are defined as emotions directly related to mastering activities or achieving results. Most emotions that are related to students' learning and mastery of subject matter at school are considered as goal achievement emotions since they are related to behavior and outcome. In previous research, goal achievement emotions were particularly linked to performance outcomes (Weiner, 1985; Pekrun et al., 2007).
Control-value theory implies that goal achievement emotions also can be linked to the experience of an activity. Emotions related to the activity itself have traditionally been overlooked in research on 'coping emotions'. Feeling of joy and pride in reaching the goals you have set, and frustration and shame when the effort fails, are examples. It can also be that one feels anger at assignment requirements, or that one is bored in class. In other words, boredom is one of the activity-related emotions. When students assess the value of the activity as negative, and the control too low, researchers claim that boredom has occurred. They explain it as follows:

\begin{abstract}
.. if demands are too low, as in monotonous routine activities, there may be insufficient challenge and a lack of intrinsic value, thus producing boredom. Conversely, if demands exceed capabilities and cannot be met, it may also be difficult to detect meaning in the activity, thus reducing its value. Furthermore, subjectively devaluing material that is too difficult may serve to cope with the threat implied by high demands (Pekrun et al. 2007, p.21).
\end{abstract}

It is also emphasized in the control-value theory that goal achievement emotions affect students' cognitive resources, motivation to learn, and the use of different learning strategies (Pekrun et al., 2007; 2014). At the same time, we are talking about some of the consequences of boredom. It should not be possible to talk about academic boredom without its consequences. However, the consequences are often underestimated.

\section{Consequences of Academic Boredom}

Boredom is a common complaint in school-based learning situations, but the serious consequences it can have for students' performance and health are often undercommunicated (Gerritsen et al., 2013). Research show that there is a negative correlation between boredom on the one hand and motivation, the use of in-depth strategies, self-regulation and consequently achievements on the other. Furthermore, there seems to be a positive relationship between boredom on the one hand and irrelevant thoughts and being easily controlled by the environment on the other (Pekrun et al. 2002; Acee et al., 2010; Pekrun et al., 2014 ).

It is quite widespread in our daily life to hear statements signalizing that boredom is considered rather a trivial and temporary discomfort that can disappear with a simple change in circumstances. However studies reveal that it is important to regard academic boredom as a factor that is associated with very serious challenges and negative consequences. It is precisely because boredom has a painful side. There is a positive correlation between boredom on one hand and depression and anxiety on the other hand. Academic boredom also has a negative correlation 
with the feeling of having a meaningful life (Eastwood et al., 2012). This means that the more a student gets bored, the less meaningful life she/he feels she/he has, and the greater the chance of developing depression. In addition boredom can be a trigger for skipping school, dropping out and at last but not least reduced goal achievement.

Due to these consequences, we should be careful to say that it is trivial, because it is clear that boredom can develop into a bigger problem in students. With this in mind, there is serious work that should be done when it comes to mapping the phenomenon based on an operationalizable definition.

\section{Wanted: A Comprehensive and Operationalizable Definition}

According to Vodanovich (2003) the lack of a unanimous agreement on the definition of boredom has limited the measurements of the phenomenon. Currently it may seem that boredom is usually defined somewhat imprecisely in terms of how it feels to be bored, which indicates that the main focus is directed to define boredom by putting the main emphasis on the experiential components of boredom. While some researchers on the other hand, try to provide a definition of boredom by placing the main emphasis on the underlying mental proceses that occur when boredom arise. Eastwood et al. (2012) make an important point when they argue that

\begin{abstract}
... by definition, the bored person wishes to, but is unable to, become engrossed in satisfying activity. Boredom is the experience of being disengaged and stuck in an endless dissatisfying present (p.484).
\end{abstract}

Furthermore, they distinguish between mental processes and experiential components, and highlight the relationship between them. In a more detailed form they suggest the following perception of the phenomenon. Boredom is defined as an...

\begin{abstract}
... aversive state that occurs when we (a) are not able to successfully engage attention with internal (e.g., thoughts or feelings) or external (e.g., environmental stimuli) information required for participating in satisfying activity; (b) are aware of the fact that we are not able to engage attention and participate in satisfying activity, which can take the form of either awareness of high degree of mental effort expended in an attempt to engage with the task at hand or awareness of engagement with task- unrelated concerns (e.g., mind wandering); and (c) attribute the cause of our aversive state to the environment (e.g., 'the task is boring', 'there is nothing to do') (p. 484).
\end{abstract}

Thus, boredom, to a great extend is defined as a reluctant state. In a school context, academic boredom will be a reluctant condition one experiences in class or while working independently with school work. It can occur when the students are unable to mobilize their attention using internal information such as thoughts and feelings, or using external information such as environmental stimuli in the classroom. Academic boredom can also occur when one is aware of the fact that one is unable to attract attention and participate in a given activity. This can take the form of either an awareness that a high degree of effort will be needed, or that one is more concerned with something else that is not related to the task. This reluctant condition occurs when students attribute the cause of the condition to the environment, such as the teacher's teaching or the academic content. Furthermore, it appears that boredom is a result of different combinations of the following three elements (Eastwood et al. 2012):
a) mental processes
b) experiential components and / or
c) psychological causes.

The mental processes consist of: 1) inadequate orientation of the attention, 2) attribution of lack of attention to the environment, 3) failure in executive control processes and 4) unsuccessful attempts to attract attention through regulation of the warning system.

Furthermore, the experiential components consist of: 1) awareness of difficulties with concentration (for example: mental exertion and / or thought migration), 2) non-optimal stimulation, 3) negative emotions, 4) limitations and chaotic state, 5) subjective slow perception of time.

And when it comes to psychological causes, it is important to take into account 1) chronic weaknesses of the attentional system (eg: ADHD, diffuse acquired brain damage, etc.), 2) chronic inability to articulate a satisfactory goal of engagement and 3) chronic oversensitivity or hypersensitivity to stimuli.

The interaction between these three groups of antedecedents can cause negative experiences and trigger development of boredom in the classroom that hinders students' school-based learning. From educational and psychological perspective, it is reasonable to ask for intervension for boredom where the main aim is to prevent academic boredom in classrooms. We also have to admit that it is impossible to totally eliminate boredom our lives, neither in the classrooms. Therefor it is an important task for school professionals to help students to develop capasities and the nessesary strategies to cope with boredom as conscious individuals. 
Based on the perspectives of Pekrun et al. (2007; 2014), Daschmann et al. (2011), Eastwood et al. (2012), and Tze (2016) discussed above, we can say that creation of teaching-learning settings that prevent and help students to handle boredom necessitates following qualities:

- Variety and excitement in the class that ensure involvement

- Experiencing the content, material and learning activities as meaningfull

- Reasonable amount of stimulation and challenges

- Feeling of being in the class is better than being outside

- Good teacher-student relationship

- Interlinking learning material and practice/ daily life.

- Enthusiasm

- Student-adaptive teaching / Scaffolding in the class

- Grantig more autonomy to the students

- Positive reinforcement

- Supporting students even after failure

\section{Conclusion}

Academic boredom is a very rich concept and at the same time a widespread phenomenon. It does not have a clear and consise definitions yet. However there is a broad agreement among the researchers that academic boredom is one of many school-related emotions, and is described as a negative deactivating goal achievement emotion. Based on the current research in the field, it is clear that academic boredom can have serious negative consequences for students' school-based learning. In the long run academic boredom can also be a precursor to other deeper psychopathological conditions such as depression and anxiety. Existing research literature focuses mostly on academic boredom among undergraduate and graduate students. The restricted number of studies addressing academic boredom among elementary and secondary school students, show that there are identifyable factors in teaching-learning settings. Identifying the antecedents and presecutors can give us opertunities to develop satisfying teaching-learing enviroments that possibly can reduce academic boredom and its rise. At the same time it is utmost important to equip the young students to cope with boredom when they encounter it, and develop a form of academic stamina. The aim in this attempt is to highlight what one as a student can accoplish by not surrendering to the boredom. This can take time, but it is nevertheless in line with the origin of the German word for boredom "Langeweile": "long time".

\section{References}

Acee, T. W., Kim, H., Kim, H. J., Kim, J., Chu H.-N., Kim, M., Cho, \& Wicker, F. W. (2010). Academic boredom in under- and over-challenging situations. Contemporary Educational Psychology, 35, 1727. doi:10.1016/j.cedpsych.2009.08.002 2010.

Daniels, L.M., Haynes, T.L., Stupnisky R.H.,. Perry R.P., Newall, N., \& Pekrun, R. (2008). Individual differences in achievement goals: A longitudinal study of cognitive, emotional, and achievement outcomes. Contemporary Educational Psychology, 33, 584-608. http:// dx.doi.org/10.1016/j.cedpsych.2007.08.002.

Daschmann, E. C., Goetz, T., \& Stupnisky, R. H. (2011). Testing the predictors of boredom at schools: development and validation of the precursors to boredom scales. British Journal of Educational Psychology, 81, 421-440. doi:10.1348/00070990×526038.

Daschmann, E. C., Goetz, T., \& Stupnisky, R. H. (2014). Exploring the antecedents of boredom: Do teachers know why students are bored? Teaching and Teacher Education, 39, 22-30. http://dx.doi.org/10.1016/j.tate.2013.11.009

Eastwood, J. D., Frischen, A., Fenske, M. J., \& Smilek, D. (2012). The unengaged mind: Defining boredom in terms of attention. Perspectives on Psychological Science, 7(5), 482-495. doi: $10.1177 / 1745691612456044$

Fritea, H. \& Fritea, R. (2013). Can motivational regulation counteract the effects of boredom on academic achievement? Procedia - Social and Behavioral Sciences, 78, 135-139. doi:10.1016/j. sbspro.2013.04.266.

Fullan, M. (2014). The Principal: Three Keys to Maximizing Impact. Jossey-Bass

Gerritsen, C. J., Toplak, M. E., Sciaraffa, J. \& Eastwood, J. (2014). I can't get no satisfaction: Potential causes of boredom. Consciousness and Cognition, 27, 27-41. doi:10.1016/j.concog.2013.10.001

Goetz, T., Pekrun, R., Hall, N., \& Haag, L., (2006). Academic emotions from a social-cognitive perspective: Antecedents and domain specificity of students' affect in the context of Latin instruction. British Journal of Educational Psychology, 76, 289-308. doi:10.1348/000709905X42860 
Goetz, T., Cronjaeger, H., Frenzel, A. C., Lüdtke, O., \& Hall, N. C. (2010). Academic self-concept and emotion relations: Domain specifi city and age effects. Contemporary Educational Psychology, 35(1), 44-58. doi:10.1016/j.cedpsych.2009.10.001

Goetz, T., Lüdtke, O., Nett, U. E., Keller, M. M., \& Lipnevich, A. A. (2013). Characteristics of teaching and students'emotionsintheclassroom: Investigating differences across domains. Journal of Contemporary Educational Psychology, 38, 383394. doi:10.1016/j.cedpsych.2013.08.001

Greenson, R. R. (1953). On Boredom. Journal of the American Psychoanalytic Association, 1(1), 7-21. doi:10.1177/000306515300100102

Hill, A. B., \& Perkins, R. E. (1985). Towards a model of boredom. British Journal of Psychology, 76(2), 235-240. DOl: 10.1111/j.2044-8295.1985.tb01947.x

Larson, R. W. \& Richards, M. H. (1991). Boredom in the middle school years: Blaming schools versus blaming students. American Journal of Education, 99(4), 418-433. http://www.jstor.org/ stable/1085554

Nett, U. E., Goetz, T., \& Hall, N. C. (2011). Coping with boredom in school: An experience sampling perspective. Contemporary Educational Psychology, 36(2011), 49-59. doi:10.1016/j. cedpsych.2010.10.003

Øia, T. (2011). Ungdomsskoleelever: Motivasjon, mestring og resultater. (NOVA rapport 9/11). Oslo: NOVA. http://www.nova.no/asset/4604/1/4604_1.pdf

Patrick, B. C., Skinner, E. A., \& Connell, J. P. (1993). What motivates children's behavior and emotion? Joint effects of perceived control and autonomy in the academic domain. Journal of Personality and Social Psychology, 65(4), 781-791.

Pekrun, R., Goetz, T., Titz, W., \& Perry R. P. (2002). Academic emotions in students' selfregulated learning and achievement: A program of quantitative and qualitative research. Educational Psychologist, 37, 91106. http://kops.uni- konstanz.de/ bitstream/ handle/123456789/13885/Pekrun_Goetz_2002_ academic\%20 motions-.pdf?sequence=2

Pekrun, R. (2006). The control-value theory of achievement emotions:Assumptions, corollaries, and implications for educational research and practice. Educational Psychology Review, 18. 315-341. doi:10.1007/s10648-006-9029-9
Pekrun, R., Frenzel, A., Goetz, T., \& Perry., R. P. (2007). The control-value theory of achievement emotions: An integrative approach to emotions in education. In: P.A. Schutz \& R. Pekrun (Red.), Emotions in education. (13-36). San Diego: Academic Press.

Pekrun, R., Goetz, T., Daniels, L. M., Stupnisky, R. H., \& Perry R.P. (2010). Boredom in achievement settings: Exploring control-value antecedents and performance outcomes of a neglected emotion. Journal of Educational Psychology, 102(2010), 531-549.

Pekrun, R.; Hall, N., C.; Goetz, T., \& Perry, R.P. (2014). Boredom and academic achievement: Testing a model of reciprocal causation. Journal of Educational Psychology, 106(3), 696-710. doi:10.1037/a0036006

Pekrun, R., Goetz, T., Daniels, L. M., Stupnisky, R. H., \& Perry R.P. (2010). Boredom in achievement settings: Exploring control-value antecedents and performance outcomes of a neglected emotion. Journal of Educational Psychology, 102(2010), 531-549.

Pekrun, R., Muis K. R., Frenzel, A. C., \& Goetz, T. (2018). Emotions at school. New York: Routledge

Price, D., Jackson, D. Hannon, M.H. V. \& Patton, A. (2012). The Engaging School - A Handbook for school leaders. London: Published by the Paul Hamlyn Foundation.

Robinson, W.P. (1975). Boredom at school. British Journal of Educational Psychology, 45(1975), 141-152.

Stavrova, O., \& Urhahne, D. (2010).Modification of a school programme in the Deutsches museum to enhance students; attitudes and understanding. International Journal of Science Education, 32, 2291-2310. doi:10. 1080/09500690903471583.

Sørlie, M.-A. \& Nordahl, T.(1998). Problematferd i skolen. Hovedfunn, forklaringer og pedagogiske implikasjoner. (NOVArapport 12a/98). Hovedrapport fra forskningsprosjektet. "Skole og samspillsvansker". Oslo: NOVA

Thuen, E. \& Bru, E. (1999). Læringsmiljø og konsentrasjon blant elever i 6. og 9.klasse. (1. Utg) Høgskolen i Stavanger (UiS): Senter for atferdsforskning. 
Tze, M.C V., Daniels, L. M., \& Klassen, R. M. (2016). Evaluationg the Relationship between Boredom and Academic Achievement: A Meta-Analysis. Educational Psychology Review, 28(1), 119-144. https://doi.org/10.1007/s10648-015-9301-y

Tze, V. M. C., Klassen, R. M., \& Daniels, L. M. (2014). Patterns of Boredom and Its Relationship With Perceived Autonomy Support and Engagement. Contemporary Educational Psychology, 39, 175187.

Sundberg, N. D., Latkin, C. A., Farmer, R. F., \& Saoud, J. (1991). Boredom in young adults: Gender and cultural comparisons. Cross-Cultural Psychology, 22(2), 209-223.

Vodanovich, S. J. (2003). Psychometric measures of boredom: A review of the literature. The Journal of Psychology: Interdisciplinary and Applied, 137(6), 569-595. http://search. proquest.com/docview/213831746/fulltextPDF/ DFC7152EODDB4521P Q/1?accountid=14699

Vogel-Walcutt, J., Fiorella, L., Carper, T., \& Schatz, S. (2012). The definition, assessment, and mitigation of state boredom within educational settings: a comprehensive review. Educational Psychology Review, (24), 89-111. http://link.springer.com/ article/10.1007/s10648-011-9182-7/fulltext.html

Weiner, B. (1985). An attributional theory of achievement motivation and emotion. Psychological Review, 92(1985), 548-573. http://dx.doi.org/10.1037/0033$295 \times .92 .4 .548$ 